\title{
Factors Influencing Teachers' Online Teaching Competence in Higher Education
}

\author{
Benjamin Aidoo $^{1^{*}\left({ }^{(}\right)}$, Allyson Macdonald $^{1}{ }^{\circledR}$, Alexander Obiri Gyampoh $^{2}{ }^{(}$, Kennedy Ameyaw Baah $^{3(}$, \\ Johnson Tsyawo 4
}

${ }^{1}$ School of Education, University of Iceland, Iceland

${ }^{2}$ Department of Science Education, Kibi Presbyterian College of Education, Ghana

${ }^{3}$ Department of Science Education, Wesley College of Education, Ghana

${ }^{4}$ Science Education, Jasikan College of Education, Ghana

Email: ogarzy34@gmail.com

Received: 08 January 2022; Revised: 11 February 2022; Accepted: 11 February 2022

\begin{abstract}
The purpose of this research was to determine Ghanaian teachers' competencies in delivering online lessons. Transitioning face-to-face instructions to an online environment presents difficulties for instructors, particularly teachers and students doing so for the first time. The researchers explore how teachers in disrupted schools use information and communications technology (ICT) in their classrooms that differ in several ways from the regular classroom. The researchers investigated the factors influencing teachers' online instruction competence. A questionnaire was used to collect data from teachers in three teacher training colleges in Ghana in the 2021 academic year. Results showed that teachers had adequate knowledge of ICT. Also, ICT knowledge was strongly correlated to ICT usage. Regression analysis revealed that teachers could become competent and effectively teach online courses by having adequate knowledge, regularly using ICT, and receiving technical support from the institution. These findings suggest that teachers need sufficient knowledge and support to use computers to become competent in integrating ICT into their online course delivery.
\end{abstract}

Keywords: COVID-19, online teaching, competence, ICT knowledge, professional development

\section{Introduction}

Many schools worldwide shifted to remote teaching and learning because the COVID-19 pandemic disrupted regular classroom meetings. This disruption seems to have severe implications and challenges for teaching practice, especially teacher-student communication, which calls for alternative teaching and learning methods (Opara, 2020). These alternative forms involved a rapid transformation with emerging digitalization and available ICT resources in schools and universities (McFarlane, 2019). During the pandemic, most instructors introduce learning materials via the internet with video podcasts and social networking for communication and effectively to support students' learning (McGarr, 2009). Since the inception of online learning, teachers have been somehow relieved due to the availability of technological tools. Aljaraideh and Al Bataineh (2019) reiterated that the availability and improvement of ICT tools have resulted in the effective delivery of quality online learning.

Copyright (C2022 Benjamin Aidoo, et al.

DOI: https://doi.org/10.37256/ser.3120221315

This is an open-access article distributed under a CC BY license

(Creative Commons Attribution 4.0 International License)

https://creativecommons.org/licenses/by/4.0/ 
Ghana's ICT policy has frequently focused on how $21^{\text {st }}$-century students must learn (Ministry of Education, 2015). As part of the curriculum reforms, much emphasis was placed on ICT as a teaching and learning tool to facilitate students' possible career options (GoG, 2003). ICT integration was meant to improve teaching and learn at all levels and encourage ICT literacy development among students (CRDD, 2010). Ultimately, an investment was made in all levels of education to help accelerate the overall information revolution. For these commitments, the Ministry of Education distributed 1,000 laptops to 30 institutions throughout the nation and another 2,500 computers to 2,000 elementary schools to harness the one laptop per child (OLPC) project (Asante \& Owusu-Ansah, 2015; Buchele \& Owusu-Aning, 2007). Teachers and lecturers received extensive training on ICT literacy and skills (Buabeng-Andoh \& Yidana, 2015).

Consequently, the ICT ideology has been revised over time with expectations that graduates can develop requisite skills and knowledge and become creative to use ICT tools for global knowledge communication. However, most of the initiatives have failed to achieve its objective. For example, an ICT policy document was developed yet, or was not implemented fully; distance education at higher institutions was delayed (Antwi et al., 2018). Also, unequal educational infrastructure, including computers, internet access, and other forms of technology, especially between urban and rural schools (Buabeng-Andoh \& Yidana, 2015). Such detailed analysis shows that Ghana's primary and secondary education sector is underdeveloped in terms of the utilization of technology.

\subsection{Background: transitioning to online teaching and learning: Ghana's story}

Online teaching employs different pedagogical practices to teach and learn towards an individual objectivist approach with enhanced constructivist and group-oriented approaches (Toven-Lindsey et al., 2015). The delivery of online instructions involves restructuring a face-to-face classroom course integrated with technology (Chiasson et al., 2015). Teaching and learning with new technology require designing classroom learning spaces connected to the internet (Aboagye, 2021). It also involves audio or videotaped materials or podcasts shared online to turn students into participatory individuals with assignments and discussions shared on the learning management system.

The sudden transition from in-person to remote teaching and learning brought many challenges among teachers and students in schools and universities. When remote education became a reality, many teachers had to adjust radically to their work schedules and teaching methods (Sakyili, 2019). Several developed countries had sufficient digital infrastructure as a valuable tool to enhance distance and online learning. However, in most African countries, a failure rate in delivering online lessons is due to a lack of ICT infrastructure (Tanye, 2017; Chirwa, 2018; Egielewa et al., 2021). Many researchers have also mentioned teachers' deficient skills, knowledge, beliefs, time availability, and engagement to use ICT (Agyei \& Voogt, 2014). Other studies have indicated lack of access to electricity and power supplies in classrooms impedes teacher implementation of ICT practices and online learning (Arthur-Nyarko \& Kariuki, 2019). Natia and Al-hassan (2015) found that the application of ICT by teachers revealed limited competencies, lack of efficacy creativity, lack of internet, and insufficient computers as factors mitigating against online learning in Ghana.

With the increase in demand for programmatic education, prior studies had shown situations where teachers and students exhibit a substantial disparity in their readiness for online learning. Some studies reported numerous challenges teachers and students faced in Ghana. These include students' lack of technological proficiency and data cost needs (Henaku, 2020), lack of technical support for teachers, lack of knowledge and skills to use technological tools (Aboagye, 2021). Additionally, access to the internet connection, inadequate technological skills, insufficient technical support, lack of ICT policies, lack of infrastructures such as computers, and inappropriate content mitigate against effective ICT integration into the school curricula (Gyampoh et al., 2020).

These challenges affected teachers' competence to use remote- and web-based tools and instead tried to conduct instruction using digital platforms leading to a call to halt online learning. Consequently, teachers became unprepared to design their courses to remote teaching and learn with technology due to the lack of policies on emergency remote teaching. However, other studies revealed teachers' preparedness for remote education. Many tertiary cycle teachers received training to successfully acquire skills, knowledge, and competencies to transform virtual instruction (Quaicoe \& Pata, 2018). This implies that teachers had pedagogical competencies to implement online learning in schools (Bariham et al., 2020).

Despite the disparities and challenges of online teaching, teachers are expected to transform their face-to-face classroom activities into an online learning environment. Teachers are expected to develop pedagogical practices to improve their ICT competencies to work with digital technologies (Cabero-Almenara \& Llorente-Cejudo, 2020). 
Teachers needed to require technology-related pedagogical training and support to develop ICT competencies and improve their teaching in an online environment (Heitinka et al., 2016).

In Ghana, university teachers and tutors shifted their regular face-to-face classrooms to online teaching despite these challenges. It was assumed that this set of teachers had some form of ICT knowledge and was ready to transform their teaching online with little or no training. Teachers are also expected to have some distance learning experience and adapt quickly to online teaching despite the challenges. Most teachers used virtual communication and digital tools, and these innovative opportunities enhanced their knowledge and competence to teach their courses online effectively. But what remains unclear is which factors improved the teachers' competence and which lessons are learned going forward. Against this background, this paper presents teachers' experience transitioning their courses virtually. The researchers investigate teachers' perceptions and competencies in delivering online lessons. The following research questions guided the study:

1. What characterizes teachers' ICT knowledge for online teaching?

2. What is the relationship between knowledge in ICT and the use of ICT in teaching?

3. To what extent do teachers' ICT knowledge, ICT training, organization capacity and resources, regular ICT, and online learning experience enhance online teaching competence?

Hypothesis:

1. Teachers have no different levels of ICT knowledge in teaching online.

2. There is no relationship between ICT knowledge and regular use of ICT.

3. High knowledge in ICT, regular use of ICT, institutional resources and support, ICT-related training, and online learning experience predict teachers' online teaching competence.

\subsection{Literature review}

Individual, institutional, and technological factors play a significant role in adopting ICT into teaching. Therefore, teachers need the requisite information, instructional skills, and proper support for moving from a face-to-face environment to an online setting. Researchers have identified factors that characterize teachers' ICT adoption, an essential requirement for online teaching. These factors include personal characteristics, institutional factors, and learning experience. The literature in this section examines these topics in greater depth.

\subsubsection{Personal characteristics}

Personal attributes such as age, gender, personality, and values can significantly affect people's attitudes, preparedness, and technology usage (González-Sanmamed et al., 2017). Studies have shown that the attitudes and integration of technology in teaching are strongly positive. Scott (2016) found that beliefs and attitudes towards technology change over time influence one's decision to integrate ICT into one classroom practice. Teachers feel challenged to implement online teaching due to their pedagogical beliefs, self-confidence, and prevalence of the technology in the market (Howard et al., 2015). Chen and Jang (2014) asserted that teachers' attitudes and teacher knowledge are critical factors in determining how effectively they integrate technology into their teaching.

Other studies have found teacher motivation and technology integration results from teachers' perception of ICT teaching. Al-Emran et al. (2016) argued that the main barrier to teacher technology usage in education is teachers' role in learning. On the other hand, Chan et al. (2017) emphasized that teachers' mixed attitude toward technology significantly affects the successful implementation of technology in their classrooms.

\subsubsection{Teacher knowledge, skills, and competence for online teaching}

The development and use of technological tools for communication, collaboration, information sharing, and knowledge sharing have become more widespread. Integrating these technological tools into teaching demands some knowledge and skills from teachers to sufficiently use them. Teachers' ICT competence and attitudes have been identified as initial and future classroom critical factors for technology integration (Lawrence \& Tar, 2018). Several studies have reported a strong relationship between teachers' ICT knowledge, competence, and integration into teaching. Aslan and Zhu (2015) found that their confidence and competencies positively influence teachers' ICT integration in 
teaching in ICT. Sipilä (2014) mentioned that teachers who know how to employ ICT technologies effectively positively affect their students' skill mastery of technology. Similarly, Cakir and Yildirim (2013) studied teachers' perceptions of ICT skills and capabilities and concluded that teachers' competencies are essential for their ICT professional learning.

In response to the call for ICT integration for online teaching, teacher knowledge has been extended to include mastering challenges associated with ICT usage (Niess \& Roschelle, 2018). Teachers' know-how is a critical success factor in technology use and application (Mouza et al., 2014). Zhang et al. (2019) argued that teachers should have a solid understanding of technology to apply it successfully. Regrettably, most teachers cannot teach effectively using technology, and many of them report difficulties in integrating technology effectively into their teaching (Ertmer \& Ottenbreit-Leftwich, 2010). Ab Kadir (2017) explained that teachers' technological pedagogical knowledge should include technology for teaching and learning in all situations and not subject-specific. This implies that teachers' competence to apply technology to pedagogical concepts and teaching practices is independent of subjects (König et al., 2020).

While online instruction can be beneficial in different ways, transitioning a lecture format to an active learning environment poses a challenge to teachers, especially for teachers experiencing design and implementation for the first time. Teachers changing roles requires skills and commitment, such as knowledge to create videos and use the learning management systems. Therefore, teachers must combine experience with pedagogical content and technological pedagogy (Criu \& Marian, 2014). Wang (2017) stated that teachers are reluctant to use online teaching due to a lack of understanding using their classroom skills. Therefore, teachers must be well equipped with skills and knowledge to assist students in developing an emotional connection with technology-integrated learning.

\subsubsection{Institutional resources and support}

Successful implementation of online learning has been linked to institutional support, and available resources teachers receive. No matter the focus of online learning, teachers need additional instructional help to embrace and utilize ICT to transfer their courses virtually (Neyland, 2011). Research has shown that technologically inclined leaders support teacher competency development in the technology use (Yusoff \& Tengku-Ariffin, 2020; Buabeng-Andoh, 2012). Thannimalai and Raman (2018) asserted that institution administrators should provide extensive support on educational technology for teachers as it enhances or reduces ICT usage by teachers in the classroom. Ingersoll and Strong (2011) explained that the type of preparation system, instruction, and support for teachers allows them to work effectively and nurture other teachers. School leaders must ensure they understand new practices, support, monitor teacher perspectives, and provide teachers with additional skills to carry out the expected change (Mingaine, 2013). Supporting teachers to implement recent classroom changes is built on a functioning system of teacher-supported personnel to facilitate professional development programs, regardless of instruction and focus.

With the abundance of new electronic communication methods and integrated technologies, emerging teachers need instructional deliveries and virtual classrooms that help them transform their lessons (Berrett et al., 2012). However, successful integration of these virtual classrooms depends mostly on availability and access to ICT facilities and resources in the institutions, e.g., computers and the internet. Buabeng-Andoh (2019) mentioned that access and availability of ICT resources in schools facilitate the easy integration of ICT into education. Resource availability has enabled the adoption and integration of innovative educational approaches for teaching to improve and enhance perception and understanding (Reimers \& Andreas, 2020). These revelations show that resource access to ICT infrastructure is essential to educational technology, especially online education.

\subsubsection{Professional development and training related to ICT usage in teaching}

Teachers should be excited about and eager to get online about the demand for technical knowledge, not terrified of it. Teachers' work experience is essential for integrating IT into the classroom. Using ICT may require training regardless of whether they have prior experience or not (Trust \& Whalen, 2020). Aydin et al. (2016) stated that activities related to ICT programs help enhance teachers' competencies in successful use for teaching. Teacher training on quality technological tools would improve teachers' ICT competence in their teaching activities. A study done by Gumbo (2020) revealed that technology training activities were positively correlated somehow with teachers' needs to use technology that helps to establish their competency and acceptance in the classroom. Teachers' background in ICT teaching is 
linked to their attitude and ability to help children learn. Kerckaert et al. (2015) concluded that the more experienced teachers have with ICT, the more likelihood of developing positive attitudes.

Indeed, the introduction of technological learning should be addressed with some foundation to guide the implementation of online teaching in colleges and universities. However, using technology in online learning is a critical factor in teachers' readiness for delivering instruction online. Thus, the call for teachers' support for teaching online requires facilitated training to use such an approach. Hence investigate the teachers' knowledge, experiences, and challenges encountered transitioning to online teaching.

\section{Methodology}

\subsection{Research design}

The study followed a descriptive case study design to investigate teachers' views and experiences in online teaching. The design was selected to investigate a phenomenon and determine the extent to which the phenomenon exists (Creswell \& Creswell, 2017). The descriptive design was appropriate for investigating the state of online teaching in Ghana and how teachers have adopted it. Researchers use a descriptive case study to describe the situation by looking at the factors that affect teachers' competence in online teaching. In that sense, we adopted the case study to examine how to transform from face-to-face teaching to have a deeper understanding of the situation.

\subsection{Sampling}

A convenient sampling technique was employed to sample teachers from colleges and universities who delivered their courses online during the Covid-19 pandemic in Ghana. Participants of this study were 77 teachers from 3 colleges of education and 2 universities from southern Ghana who delivered their courses online in the 2020/2021 academic year. The teachers had some online education experience and have taught the same courses for at least five years, so they have some good experience in the teaching service.

\subsection{Research instrument design and administering}

The questionnaire was developed and given to two independent faculty members at the University of Iceland to validate this study's questions. After the teachers' first revision, the questionnaire was then used tested as a pilot study on teachers in Iceland. Two other independent researchers (one doctoral student and one faculty member) shared their views and made recommendations. The content and context of the questions were then amended after responses from 40 teachers and postgraduate students. The questions were refined again and agreed upon among the authors before administering them for the study.

\subsection{Procedures}

The study used a questionnaire as the data collection tool with twenty 22-open-ended Likert-type scale items. The questionnaire contained items that sought teachers' views on transforming their courses virtually relating to their background and experiences during the transition. The questions on ICT knowledge were measured using a 3-point scale from No knowledge ( 1 point), moderate knowledge ( 2 points), and sufficient knowledge ( 3 points) to measure their level of ICT knowledge. The items on measuring ICT usage were measured from a 3-point scale with Do not use at all ( 1 point), sometimes use ( 2 points), and always use ( 3 points) to measure aimed at assessing how they use ICT in their teaching. The resources and institutional support items were measured using a point scale of either $1=$ No, $2=$ Yes to ascertain the type of resources and institutional support they received during the transformation to online teaching. The items on ICT-related training were measured on a five-point Likert scale ranging from strongly disagree (1 point), disagree ( 2 points), neutral ( 3 points), agree ( 4 points), and strongly agree ( 5 points). The internal consistency for the knowledge, ICT use, resources, organizational support, and ICT training scale were calculated. The Cronbach Alpha values were found to be $0.77,0.79,0.94$, and 0.82 regarding knowledge, ICT use, resources and organizational support, and ICT training. This means that the resulting coefficient reliability of the items above 0.7 is considered reliable. 


\subsection{Data analysis}

The items in each category were combined to obtain one category and analyzed using descriptive statistics, including means, standard deviations, and further statistical analysis such as Pearson correlational and multiple regression analysis to determine the relationships between the categories in SPSS Version 27.

\section{Results}

The results in Table 1 show $68 \%$ of the respondents were males, and $32 \%$ were females. Of the total, $51 \%$ were between the ages of 20 and 40, and 49\% were in the age range of 41-60 years. Most of the teachers (71\%) had 1-20 years of teaching experience, and $29 \%$ had been teaching for 21-40 years. Teachers' experience in online learning varies; only $37 \%$ had an online learning experience, with the remaining $63 \%$ had no experience in online learning.

Table 1. Demographic information of the participants

\begin{tabular}{cccc}
\hline & & Frequency & Percentage \\
\hline Gender & Male & 51 & 68.0 \\
& Female & 24 & 32.0 \\
Age & $20-40$ & 37 & 50.7 \\
& $41-60$ & 36 & 49.3 \\
Teaching experience & $1-20$ & 53 & 70.7 \\
& $21-40$ & 22 & 29.3 \\
Online learning experience & No & 48 & 63.2 \\
& Yes & 28 & 36.8 \\
\hline
\end{tabular}

\subsection{Research question 1: Characteristics of teachers' ICT knowledge}

Table 2. Teachers' characteristic ICT knowledge

\begin{tabular}{|c|c|c|c|c|c|}
\hline \multirow[b]{2}{*}{ Variable } & \multicolumn{3}{|c|}{ Percentage $(\%)$} & \multirow[b]{2}{*}{ Mean } & \multirow[b]{2}{*}{$\mathrm{SD}$} \\
\hline & $\begin{array}{l}\text { Sufficient } \\
\text { knowledge }\end{array}$ & $\begin{array}{c}\text { Moderate } \\
\text { knowledge }\end{array}$ & $\begin{array}{c}\text { No } \\
\text { knowledge }\end{array}$ & & \\
\hline Application of ICT in teaching & 37.3 & 60.0 & 2.7 & 2.35 & 0.53 \\
\hline Searching for information on the internet & 60.8 & 39.2 & 0.0 & 2.61 & 0.49 \\
\hline Finding useful information on the curriculum & 57.3 & 40.0 & 2.7 & 2.55 & 0.55 \\
\hline Pedagogical approaches with ICT & 29.3 & 62.7 & 8.0 & 2.21 & 0.58 \\
\hline Knowledge on using digital tools and software & 31.5 & 61.6 & 6.8 & 2.25 & 0.57 \\
\hline Overall ICT knowledge & 43.2 & 52.7 & 4.0 & 2.44 & 0.50 \\
\hline
\end{tabular}


In Table 2, 97\% of the teachers believed they had relevant ICT knowledge for teaching, and 3\% have indicated they had no ICT knowledge. All the teachers had high knowledge efficacy in searching for information on the internet, and $97 \%$ agreed they had knowledge on finding valuable information on the curriculum on the internet. This indicates that most teachers can navigate the internet for relevant information and general use. About $93 \%$ of teachers indicated they could use and apply ICT for various pedagogical practices. The teachers also indicated their knowledge of different digital ICT tools and software to teach. In addition, the overall ICT knowledge was around 96\% showing the teachers have basic ICT knowledge $(\mathrm{M}=2.44, \mathrm{SD}=0.50)$.

\subsection{Research question 2: Relationship between teachers' knowledge and usage of ICT}

Before analyzing how teachers' ICT knowledge relates to their online classroom practices, the teachers' ICT usage for teaching was shown in Table 3.

Table 3. Teachers' characteristics of ICT usage and practices in teaching

\begin{tabular}{|c|c|c|c|c|c|}
\hline \multirow{2}{*}{ Variable } & \multicolumn{3}{|c|}{ Percentage $(\%)$} & \multirow{2}{*}{ Mean } & \multirow{2}{*}{ SD } \\
\hline & Always & Sometimes & Not at all & & \\
\hline Create a virtual classroom for teaching & 6.7 & 61.3 & 32.0 & 1.75 & 0.57 \\
\hline Create Google docs and PowerPoints & 25.3 & 45.3 & 29.3 & 1.96 & 0.74 \\
\hline Use simulations, virtual and e-labs & 8.0 & 44.0 & 48.0 & 1.60 & 0.64 \\
\hline Create and use interactive webpages & 4.0 & 50.7 & 45.3 & 1.59 & 0.57 \\
\hline Make videos of concepts and tasks & 5.3 & 54.7 & 40.0 & 1.65 & 0.58 \\
\hline Provide support for students online & 11.0 & 58.9 & 30.1 & 1.81 & 0.62 \\
\hline Overall usage of ICT for teaching & 10.1 & 52.5 & 37.5 & 1.73 & 0.62 \\
\hline
\end{tabular}

The teachers' usage of ICT concerning their classroom activities was varied. The overall teachers' usage and classroom practices was $63 \%(\mathrm{M}=1.73, \mathrm{SD}=0.62)$. As indicated in Table 3, a majority $(68 \%)$ of the teachers can create and use a virtual classroom to a teacher $(\mathrm{M}=1.75, \mathrm{SD}=0.57)$. During the online teaching, $70 \%(\mathrm{M}=1.81, \mathrm{SD}$ $=0.62$ ) of the teachers support the students in discussions and answer their questions compared to online $30 \%$ who do not support them. Also, 71\% of the teachers can create google docs and use PowerPoint for delivering their lessons $(\mathrm{M}=1.96, \mathrm{SD}=0.74)$. The Pearson correlation test was performed to examine the relationship between teachers' ICT knowledge and ICT usage. The results show a moderately strong positive correlation $(\mathrm{r}=0.42, p<0.01)$ between ICT knowledge and ICT usage. This positive correlation implies that teachers are more likely to integrate and use ICT in their classrooms if teachers acquire higher ICT knowledge.

\subsection{Research question 3: Factors influencing teachers' ICT competence in teaching}

The assumption of multicollinearity was checked to do the multiple regression. A correlation between 0.3 to 0.49 and 0.5 to 0.8 shows a moderate and high correlation, respectively (Cohen, 1988). In Table 4 , the results of the correlations show ICT use in teaching had the strongest correlation with online teaching competence $(\mathrm{r}=0.87, p<0.01)$ followed by knowledge in ICT $(\mathrm{r}=0.80, p<0.01)$ and ICT training $(\mathrm{r}=0.61, p<0.01)$. Organizational support and resources correlated moderately $(\mathrm{r}=0.41, p<0.01)$ while experience in online learning correlated weakly with online teaching competence $(\mathrm{r}=0.27, p<0.05)$ and do not pose any concern for the multicollinearity assumption. 
Table 4. Correlations between the contributing factors of ICT competence

\begin{tabular}{ccccccc}
\hline Variable & 1 & 2 & 3 & 4 & 5 & 6 \\
\hline 1. Competence & - & & & & & \\
2. Knowledge & $0.80^{* *}$ & - & & & & \\
3. Use & $0.87^{* *}$ & $0.42^{* *}$ & - & & & \\
4. Resources & $0.41^{* *}$ & $0.29^{* *}$ & $0.34^{* *}$ & - & & \\
5. Experience & $0.27^{*}$ & 0.21 & $0.27^{*}$ & $0.25^{*}$ & - & \\
6. Training & $0.61^{* *}$ & $0.48^{* *}$ & $0.55^{* *}$ & $0.47^{* *}$ & 0.13 & - \\
\hline
\end{tabular}

Note. ${ }^{* *} . \mathrm{p}<0.01 .^{*} . \mathrm{p}<0.05$

A multiple regression analysis results in Table 5 show the impact of sufficient ICT knowledge, regular ICT usage, online learning experience, ICT training, and support and resources on delivering online lessons. The $\mathrm{R}^{2}$ value of 0.98 revealed the predictors explained $98 \%$ variance in the outcome variable with $\mathrm{F}(5,60)=540.30), p<0.01$. The findings suggest that knowledge in ICT $(\beta=1.04, p<0.01)$ and regular ICT usage $(\beta=1.33, p<0.01)$ positively predicted online teaching competence. However, institutional resources and support $(\beta=0.19, p=0.016)$, training in ICT $(\beta=$ $0.01, p=0.522)$, and online learning experience $(\beta=-0.04, p=0.830)$ has no significant effect on online teaching competence. This suggests that teachers' sufficient knowledge about ICT and regular use of ICT in teaching could contribute to their competency to deliver online lessons.

Table 5. Regression results for factors predicting ICT competence for online teaching

\begin{tabular}{ccccc}
\hline Variable & $\beta$ & SE & $\mathrm{t}$ & $\mathrm{p}$ \\
\hline Constant & -5.598 & 0.345 & -16.242 & 0.000 \\
KNW & 1.038 & 0.045 & 23.286 & $0.000^{* *}$ \\
TRN & 0.012 & 0.019 & 0.643 & 0.522 \\
RES & 0.191 & 0.077 & 2.471 & $0.016^{* *}$ \\
OLE & -0.038 & 0.177 & -0.215 & 0.830 \\
USE & 1.332 & 0.052 & 0.611 & $0.000^{* *}$ \\
\hline
\end{tabular}

Note. ${ }^{* *} . \mathrm{p}<0.01$

\section{Discussions}

The purpose of this study was to explore how teachers adopted online teaching and their competency in delivering online lessons. The study results show that teachers had high ICT knowledge regarding the first research question. The teachers reported higher levels of different dimensions of ICT knowledge for teaching. The highest and lowest mean scores on ICT knowledge were searching for information on the internet and pedagogical approaches with ICT, respectively. These results align with studies that showed higher levels of applying ICT and using it for different pedagogical approaches applicable (Chirwa, 2018).

Teachers showed various ways of using ICT in teaching. The results revealed that teachers mostly use ICT to create 
Goggle docs and PowerPoint presentations to support students during classroom discussions, simulations, and virtual labs. A strong positive correlation was found between knowledge and usage of ICT. The results showed that increased teacher knowledge enhances the regular use of ICT in teaching. When teachers have higher skills or knowledge in ICT, they develop a positive view of using technology (Martín et al., 2020; Lawrence \& Tar, 2018). This implies that teachers' knowledge and skills in technology influence technology use in teaching and learning. The findings suggest that teachers are more likely to integrate and use ICT to teach if they have the requisite knowledge and ICT skills. In addition, the teachers reported creating and using an online classroom to offer face-to-face interactions for collaborative learning and effective communication. This indicates that most teachers can develop confidence and skills in ICT if they regularly use it.

This study found a strong positive relationship between ICT competence, ICT training, institutional support and resources, ICT knowledge, and a moderate online learning experience. The results indicate that teachers can deliver online lessons when they are given the needed support from the institution in the form of technical training and ICT infrastructure. Teachers can develop their ICT competence from the teaching goals through teachers' professional development and support to enhance the technological learning environment involving available resources, technical knowledge, and personal beliefs (Twining, 2014).

The results from the multiple regression show that knowledge in ICT, institutional support and resources, and regular use contributed significantly to the prediction of ICT competency while training and experience did not. Knowledge in ICT was an essential factor for teachers' ICT competency to teach online. The findings indicated that ICT knowledge was a significant predictor of teachers' ICT competence in their teaching. Integration of ICT requires some level of competency to enable them to use digital tools for teaching. This study indicates that teachers' knowledge in ICT enhanced their technology usage as they applied the knowledge into practice. As Ertmer and Ottenbreit-Leftwich (2010) emphasized, knowledge in ICT is necessary; teachers should also be confident in using that knowledge in teaching. This implies that teachers should move beyond "ICT literate" and integrate ICT into their teaching to become "ICT competent" (Smarkola, 2008; Ventayen, 2020).

Additionally, this study found a strong relationship between institutional resources and support influencing ICT their competencies for pedagogical activities in online teaching. Most of the teachers ascribed positively to the fact that institutional support and resources helped them effectively to deliver their lessons. As indicated in previous research, institutional resources and support such as access to ICT tools, software, and the internet correlate to teachers' ICT integration in teaching and implementing e-learning (Eteokleous, 2008). Therefore, universities and schools must invest in ICT infrastructure to effectively boost teachers' work to utilize technology in their classroom activities.

However, ICT-related training positively correlated with ICT competence but did not significantly predict teachers' competence to deliver online lessons. These study findings imply that teachers' ICT training is not a predictive factor influencing their competence in teaching online. This affirmed similar research that ICT-related training did not help teachers use ICT to teach (Canals \& Al-Rawashdeh, 2019). Training is recognized as having an important impact on sustaining teachers to stay more confident in their skill acquisition by their involvement in ICT-based teaching. Therefore, ICT training for teachers must focus on access to technology and identify individual teachers' attitudes on technology integration to change the content of face-to-face to online lessons.

Lastly, previous experience in online learning did not correlate and predicted competence for online teaching. The low correlation between prior experience in online knowledge and ICT competency could be accounted for because the teachers are less acquainted with the ICT curriculum and integration during their teacher training or teaching years. As Adarkwah (2021) mentioned, teachers must have used ICT to learn and have some experience but are not competent to use it to teach. This implies that teachers' interest in using ICT in teaching and learning in a digitalized environment is driven by the teachers' understanding to conceptualize, particularly from ICT experience.

\subsection{Limitations}

This study was limited to only university and college of education teachers in southern Ghana. Because of the sample size, it is difficult to generalize the results. Further research could include a more significant sample size, especially to cover teachers from other regions and secondary school teachers to understand teachers' acceptance of online teaching better. 


\section{Conclusion and recommendation}

The purpose of this study was to explore how teachers adopted online teaching and their competency in delivering online lessons. In conclusion, this study found that the success of teachers offering online classes depends on their ICT knowledge, institutional resources, and support to use ICT regularly to teach. Teachers' views on integrating technology into their classroom practices influence their personal beliefs, attitudes, and motivation. Thus, to improve the design and implementation of online teaching, reflection should be given on teachers' knowledge, incentive to use ICT regularly, institutional support to accomplish the required operation.

This study revealed the teachers had adequate knowledge in ICT, but how to use that knowledge can be applied frequently in the classroom was not anything that the teachers were comfortable with. There were divisive reports from the teachers and their regular use of ICT because of the lack of digital tools, skills, and challenges related to internet access. The study finds teachers' knowledge in ICT strongly correlated with ICT use in teaching. The study's findings suggested that teachers have the requisite ICT knowledge and skills, but how to use the knowledge is a challenge. As a result, teachers are not that confident about teaching online because of a lack of resources and support in digital tools in education. In addition, the study explores factors that influenced the teachers' competence to deliver online lessons. The findings revealed that knowledge, regular ICT usage, and support and resources strongly correlate with teachers' competence. The teachers were not trained to be proficient enough but relied on help from colleagues instead of the institution.

Further, the study results can be used for teacher training programs and teacher development to reflect teachers' knowledge and use of ICT in schools. The results can help teachers change their beliefs and attitudes towards ICT integration to develop their teaching. From the results, in implementing online lessons, there is a demand for teachers' adequate preparation, institutional resources, support, and training for teachers to achieve $21^{\text {st }}$-century goals of integrating ICT into teaching. By making ICT professional development on pedagogical practices, teachers can organize training to share ideas to build a learning community. Some teachers could benefit from expertise experience from continuous ICT support services with guidance. The workshop could also be a dialogue form to offer theoretical knowledge and teaching and improve teachers' pedagogical knowledge.

\section{Acknowledgments}

We want to express our gratitude to all teachers who responded to the questionnaire and teachers from the University of Iceland who gave assistance and advice to make up this research.

\section{Conflict of interest}

The authors declare no conflict of interest.

\section{References}

Ab Kadir, M. A. (2017). What teacher knowledge matters in effectively developing critical thinkers in the 21 st century curriculum? Thinking Skills and Creativity, 23, 79-90. https://doi.org/10.1016/j.tsc.2016.10.011

Aboagye, E. (2021). Transitioning from face-to-face to online instruction in the COVID-19 era: Challenges of tutors at colleges of education in Ghana. Social Education Research, 2(1), 9-19. https://doi.org/10.37256/ser.212021545

Adarkwah, M. A. (2021). I'm not against online teaching, but what about us: ICT in Ghana post Covid-19. Education and Information Technologies, 26(2), 1665-1685. https://doi.org/10.1007/s10639-020-10331-z

Agyei, D. D., \& Voogt, J. (2014). Examining factors affecting beginning teachers' transfer of learning of ICT-enhanced learning activities in their teaching practice. Australasian Journal of Educational Technology, 30(1), 92-105. https://doi.org/10.14742/ajet.499

Al-Emran, M., Elsherif, H. M., \& Shaalan, K. (2016). Investigating attitudes towards the use of mobile learning in higher education. Computers in Human Behavior, 56, 93-102. https://doi.org/10.1016/j.chb.2015.11.033 
Aljaraideh, Y., \& Al Bataineh, K. (2019). Jordanian students' barriers of utilizing online learning: A survey study. International Education Studies, 12(5), 99-108. https://doi.org/10.5539/ies.v12n5p99

Antwi, S., Bansah, A. K., \& Franklin, T. (2018). The information technology challenge in teaching senior high school geography in Ghana. Issues and Trends in Learning Technologies, 6(1), 16-38. https://doi.org/10.2458/azu_itet_ v6i1_antwi

Arthur-Nyarko, E., \& Kariuki, M. G. (2019). Learner access to resources for eLearning and preference for eLearning delivery mode in distance education programs in Ghana. International Journal of Educational Technology, 6(2), 1-8.

Asante, E., \& Owusu-Ansah, S. (2015). One laptop per child policy in Ghana: Any impact on teaching and learning. Library Philosophy and Practice (e-journal).

Aslan, A., \& Zhu, C. (2015). Pre-service teachers' perceptions of ICT integration in teacher education in turkey. The Turkish Online Journal of Educational Technology-TOJET, 14(3), 97-110.

Aydin, M. K., Gürol, M., \& Vanderlinde, R. (2016). Evaluating ICT integration in Turkish K-12 schools through teachers' views. Eurasia Journal of Mathematics Science and Technology Education, 12(4), 747-766. https://doi. org/10.12973/eurasia.2016.1227a

Bariham, I., Ondigi, S. R., \& Kiio, M. (2020). Preparedness of Ghanaian senior high school instructors for application of online learning in social studies instruction amid the Covid-19 pandemic. Social Education Research, 2(1), $52-$ 64. https://doi.org/10.37256/ser.212021554

Berrett, B., Murphy, J., \& Sullivan, J. (2012). Administrator insights and reflections: Technology integration in schools. The Qualitative Report, 17(1), 200-221. https://doi.org/10.46743/2160-3715/2012.1815

Buabeng-Andoh, C. (2019). Factors that influence teachers' pedagogical use of ICT in secondary schools: A case of Ghana. Contemporary Educational Technology, 10(3), 272-288. https://doi.org/10.30935/cet.590099

Buabeng-Andoh, C. (2012). Factors influencing teachers' adoption and integration of information and communication technology into teaching: A review of the literature. International Journal of Education and Development using Information and Communication Technology (IJEDICT), 8(1), 136-155.

Buabeng-Andoh, C., \& Yidana, I. (2015). Teachers' ICT usage in second-cycle institutions in Ghana: A qualitative study. International Journal of Education and Development Using Information and Communication Technology (IJEDICT), 11(2), 104-112.

Buchele, S. F., \& Owusu-Aning, R. (2007, December). The one laptop per child (OLPC) project and its applicability to Ghana. Proceedings of the 2007 international conference on adaptive science and technology.

Cabero-Almenara, J., \& Llorente-Cejudo, C. (2020). Covid-19: Radical transformation of digitization in university institutions. Campus Virtuales, 9(2), 25-34.

Cakir, R., \& Yildirim, S. (2013). ICT teachers' professional growth viewed in terms of perceptions about teaching and competencies. Journal of Information Technology Education, 12, 221-237. https://doi.org/10.28945/1889

Canals, L., \& Al-Rawashdeh, A. (2019). Teacher training and teachers' attitudes towards educational technology in the deployment of online English language courses in Jordan. Computer Assisted Language Learning, 32(7), 639-664. https://doi.org/10.1080/09588221.2018.1531033

Chan, B. S., Churchill, D., \& Chiu, T. K. (2017). Digital literacy learning in higher education through digital storytelling approach. Journal of International Education Research (JIER), 13(1), 1-16. https://doi.org/10.19030/jier. v13i1.9907

Chen, Y. H., \& Jang, S. J. (2014). Interrelationship between stages of concern and technological, pedagogical, and content knowledge: A study on Taiwanese senior high school in-service teachers. Computers in Human Behavior, 32, 79-91. https://doi.org/10.1016/j.chb.2013.11.011

Chiasson, K., Terras, K., \& Smart, K. (2015). Faculty perceptions of moving a face-to-face course to online instruction. Journal of College Teaching \& Learning, 12(4), 231-240.

Chirwa, M. (2018). Access and use of internet in teaching and learning at two selected teachers' colleges in Tanzania. International Journal of Education and Development using Information and Communication Technology (IJEDICT), 14(2), 4-16.

Cohen, J. (1988). Set correlation and contingency tables. Applied Psychological Measurement, 12(4), 425-434. https:// doi.org/10.1177/014662168801200410

Creswell, J. W., \& Creswell, J. D. (2017). Research design: Qualitative, quantitative, and mixed methods approaches. Sage publications.

Criu, R., \& Marian, A. (2014). The influence of students' perception of pedagogical content knowledge on self-efficacy in self-regulating learning in training of future teachers. Procedia-Social and Behavioral Sciences, 142, 673-678. https://doi.org/10.1016/j.sbspro.2014.07.596

CRDD-Curriculum Research and Development Division. (2010). Teaching syllabus for information and 
communications technology (core): Senior high school 1-3. Accra, Ghana: Ministry of Education Science and Sports.

Egielewa, P., Idogho, P. O., Iyalomhe, F. O., \& Cirella, G. T. (2021). COVID-19 and digitized education: Analysis of online learning in Nigerian higher education. E-Learning and Digital Media, 19(1), 19-35. https://doi. org/10.1177/20427530211022808

Ertmer, P. A., \& Ottenbreit-Leftwich, A. T. (2010). Teacher technology change: How knowledge, confidence, beliefs, and culture intersect. Journal of Research on Technology in Education, 42(3), 255-284.

Eteokleous, N. (2008). Evaluating computer technology integration in a centralized school system. Computers \& Education, 51(2), 669-686. https://doi.org/10.1016/j.compedu.2007.07.004

GoG (The Government of Ghana). (2003). The Ghana ICT for accelerated development (ICT4AD) policy. Accra: Ministry of Information and Communication.

González-Sanmamed, M., Sangrà, A., \& Muñoz-Carril, P. C. (2017). We can, we know how. But do we want to? Teaching attitudes towards ICT based on the level of technology integration in schools. Technology, Pedagogy and Education, 26(5), 633-647. https://doi.org/10.1080/1475939X.2017.1313775

Gumbo, M. T. (2020). Professional development of technology teachers: Does their training meet their needs? Perspectives in Education, 38(1), 58-71. https://doi.org/10.18820/2519593X/pie.v38i1.5

Gyampoh, A. O., Ayitey, H. K., Fosu-Ayarkwah, C., Ntow, S. A., Akossah, J., Gavor, M., \& Vlachopoulos, D. (2020). Tutor perception on personal and institutional preparedness for online teaching-learning during the COVID-19 crisis: The case of Ghanaian colleges of education. African Educational Research Journal, 8(3), 511-518. https:// doi.org/10.30918/AERJ.83.20.088

Heitink, M., Voogt, J., Van Braak, J., \& Fisser, P. (2016). Teachers' professional reasoning about their pedagogical use of technology. Computers \& Education, 101, 70-83. https://doi.org/10.1016/j.compedu.2016.05.009

Henaku, E. A. (2020). COVID-19: Online learning experience of college students: The case of Ghana. International Journal of Multidisciplinary Sciences and Advanced Technology, 1(2), 54-62.

Howard, S. K., Chan, A., \& Caputi, P. (2015). More than beliefs: Subject areas and teachers' integration of laptops in secondary teaching. British Journal of Educational Technology, 46(2), 360-369. https://doi.org/10.1111/bjet.12139

Ingersoll, R. M., \& Strong, M. (2011). The impact of induction and mentoring programs for beginning teachers: A critical review of the research. Review of educational research, 81(2), 201-233. https://doi. org/10.3102/0034654311403323

Kerckaert, S., Vanderlinde, R., \& van Braak, J. (2015). The role of ICT in early childhood education: Scale development and research on ICT use and influencing factors. European Early Childhood Education Research Journal, 23(2), 183-199. https://doi.org/10.1080/1350293X.2015.1016804

König, J., Jäger-Biela, D. J., \& Glutsch, N. (2020). Adapting to online teaching during COVID-19 school closure: Teacher education and teacher competence effects among early career teachers in Germany. European Journal of Teacher Education, 43(4), 608-622. https://doi.org/10.1080/02619768.2020.1809650

Lawrence, J. E., \& Tar, U. A. (2018). Factors that influence teachers' adoption and integration of ICT in teaching/ learning process. Educational Media International, 55(1), 79-105. https://doi.org/10.1080/09523987.2018.1439712

Martín, C. S., González, M. C., \& Peñalvo, F. J. G. (2020). Digital competence of early childhood education teachers: Attitude, knowledge and use of ICT. European Journal of Teacher Education, 43(2), 210-223. https://doi.org/10.1 080/02619768.2019.1681393

McFarlane, A. E. (2019). Devices and desires: Competing visions of a good education in the digital age. British Journal of Educational Technology, 50(3), 1125-1136. https://doi.org/10.1111/bjet.12764

McGarr, O. (2009). A review of podcasting in higher education: Its influence on the traditional lecture. Australasian Journal of Educational Technology, 25(3). https://doi.org/10.14742/ajet.1136

Mingaine, L. (2013). Challenges encountered by principals during implementation of ICT in public secondary schools, Kenya. Journal of Sociological Research, 4(2). https://doi.org/10.5296/jsr.v4i2.3552

Ministry of Education. (2015). ICT in education policy. Accra.

Mouza, C., Karchmer-Klein, R., Nandakumar, R., Ozden, S. Y., \& Hu, L. (2014). Investigating the impact of an integrated approach to the development of preservice teachers' technological pedagogical content knowledge (TPACK). Computers \& Education, 71, 206-221. https://doi.org/10.1016/j.compedu.2013.09.020

Natia, J., \& Al-hassan, S. (2015). Promoting teaching and learning in Ghanaian basic schools through ICT. International Journal of Education and Development using ICT, 11(2), 113-125.

Neyland, E. (2011). Integrating online learning in NSW secondary schools: Three schools' perspectives on ICT adoption. Australasian Journal of Educational Technology, 27(1), 152-173.

Niess, M. L., \& Roschelle, J. (2018). Transforming teachers' knowledge for teaching mathematics with technologies 
through online knowledge-building communities. Proceedings of the 40th annual meeting of the North American Chapter of the International Group for the Psychology of Mathematics Education. Greenville, SC: University of South Carolina \& Clemson University.

Quaicoe, J. S., \& Pata, K. (2018). Basic school teachers' perspective to digital teaching and learning in Ghana. Education and Information Technologies, 23(3), 1159-1173.

Reimers, F. M., \& Schleicher, A. (2020). A framework to guide an education response to the COVID-19 Pandemic of 2020. OECD.

Scott, K. M. (2016). Change in university teachers' elearning beliefs and practices: a longitudinal study. Studies in Higher Education, 41(3), 582-598. https://doi.org/10.1080/03075079.2014.942276

Sipilä, K. (2014). Educational use of information and communications technology: Teachers' perspective. Technology, Pedagogy and Education, 23(2), 225-241. https://doi.org/10.1080/1475939X.2013.813407

Smarkola, C. (2008). Efficacy of a planned behavior model: Beliefs that contribute to computer usage intentions of student teachers and experienced teachers. Computers in Human Behavior, 24(3), 1196-1215. https://doi. org/10.1016/j.chb.2007.04.005

Tanye, H. A. (2017). Quality elearning in distance learning: Benefits and implications for national elearning policy in Ghana. International Journal of Multicultural and Multireligious Understanding, 4(3), 1-11. https://doi.org/ 10.18415/ijmmu.v4i3.73

Thannimalai, R., \& Raman, A. (2018). The influence of principals' technology leadership and professional development on teachers' technology integration in secondary schools. Malaysian Journal of Learning and Instruction (MJLI), 15(1), 203-228.

Toven-Lindsey, B., Rhoads, R. A., \& Lozano, J. B. (2015). Virtually unlimited classrooms: Pedagogical practices in massive open online courses. The Internet and Higher Education, 24, 1-12. https://doi.org/10.1016/ j.iheduc.2014.07.001

Trust, T., \& Whalen, J. (2020). Should teachers be trained in emergency remote teaching? Lessons learned from the COVID-19 pandemic. Journal of Technology and Teacher Education, 28(2), 189-199.

Twining, P., \& Henry, F. (2014). Enhancing 'ICT teaching' in English schools: Vital lessons. World Journal of Education, 4(2), 12-36. http://dx.doi.org/10.5430/wje.v4n2p12

Ventayen, R. J. M. (2020). Educator's competencies on the application of technological tools in teaching. International Journal of Scientific \& Technology Research, 9(1), 4210-4215.

Wang, F. H. (2017). An exploration of online behaviour engagement and achievement in flipped classroom supported by learning management system. Computers \& Education, 114, 79-91. https://doi.org/10.1016/j.compedu.2017.06.012

Yusoff, S. M., \& Tengku-Ariffin, T. F. (2020). Looking after teacher wellbeing: Does teacher empowerment matter? MOJEM: Malaysian Online Journal of Educational Management, 8(4), 43-56.

Zhang, S., Liu, Q., \& Cai, Z. (2019). Exploring primary school teachers' technological pedagogical content knowledge (TPACK) in online collaborative discourse: An epistemic network analysis. British Journal of Educational Technology, 50(6), 3437-3455. https://doi.org/10.1111/bjet.12751 